\title{
Development of Thematic Skill Learning Based on the 21th Century Skill Model for Fourth Graders
}

\author{
Tio Gusti Satria ${ }^{1 *}$, Tri Juli Hajani ${ }^{2}$ \\ STKIP-PGRI Lubuklinggau, Indonesia \\ *satriagustio@gmail.com
}

\begin{abstract}
Thematic learning using 21st Century skills is learning with higher-order thinking skills (HOTS). It is a series of stages of activities organized in such a way that students can master the competencies that must be achieved in thematic learning by actively participating. This research is educational research with a design research model that develops a product. The product developed in this study is a thematic lesson plan for grade IV elementary school. Thematic learning implementation plan based on 21st Century skills models with an overall validation yield of $92 \%$ (very valid). The thematic learning media is very practical with an average of $92.5 \%$. The effectiveness of the use of thematic lesson plans can be known through the learning activities of students while learning by using this learning tool is very effective, and students' learning outcomes are above the school minimum completeness criteria. These observations illustrate that the use of thematic lesson plans based on 21st Century skills models have been effectively implemented.
\end{abstract}

Keywords: 21st Century skills; learning implementation plan; thematic learning.

\section{INTRODUCTION}

Learning media are basically a form of learning procedures and management to achieve the basic competencies set out in the content standards (curriculum standards). Based on Permendikbud No. 22 of 2016 it was concluded that the learning device affects the learning process. Learning media that are designed can facilitate the realization of interactive, inspiring, fun, and challenging learning. Learning that can motivate active students, as well as provide sufficient space for the development of initiatives, creativity, and independence in accordance with the talents, interests and physical and psychological development of students. Through good Learning media the learning process will be more meaningful. Learning Implementation Plan is a learning tool that can support the learning process. Learning Implementation Plan is a form of learning procedures and management to achieve basic competencies that have been set in the content standards (curriculum standards) (Daryanti \& Aris, 2014: 87). 
Journal of Teaching and Learning in Elementary Education (JTLEE)

Vol. 3 No. 1, February 2020

(C)All rights reserved

Printed in Indonesia
ISSN (Print) : :2615-4528

ISSN (Online) : 2622-3023

DOI: http://dx.doi.org/10.33578/jtlee.v3i1.7825
Analysis of thematic Learning media used in the field at this time, especially Learning Implementation Plan is in accordance with the Core Competencies and Basic Competencies related, but in the preparation of the Learning Implementation Plan does not pay attention to the rules that have been set, related to the components of the learning implementation plan, and not yet based on the 2013 revised edition curriculum. In addition, Learning media have not yet been adapted to thematic learning goals and student characteristics. The results of the analysis of the learning kit can be detailed as follows: first: Learning Implementation Plan; The writing of core competency and basic competencies is not understood correctly, when lowering basic competencies to be an indicator of not paying attention to the rules of compilation based on operational verbs, writing learning objectives has not yet drawn the main elements of the formulation of learning objectives namely $A B C D$ (Audience, Behavior, Condition, Degree) (Permendikbud 22, 2016 about Process Standard Elmentary School and Junior High School)

Learning illustrated in the lesson plan is still dominated by the teacher with lecture, question and answer, practice, and assignment methods, the lesson plan used by the teacher does not describe the learning process that activates students, is interactive, inspiring, has not been able to facilitate students to build their own knowledge and develop knowledge that is they had before.
This was proven through learning activities that began with listening to the teacher's explanation in the form of problem solving procedures related to the material followed by the completion of sample questions. Besides that, in lesson plans in general learning activities have not been clearly or specifically described (observing, asking, trying, reasoning, and communicating), at each point the activities have two or three activities that will be carried out, so that the activities of students and teachers have not been described clearly.

The use of lesson plans as described above results in a monotonous learning process, where the teacher is more active than students, resulting in the learning process is still a transfer of knowledge from teacher to student. Overcoming the thematic lesson plans used so far. Then it is necessary to develop effective, efficient, and creative lesson plans and are oriented towards student characteristics. The development of lesson plans is more effective if learning media can help students find what they want to know by finding the information they need and constructing what they already know. So it should be designed learning based on constructivism view, where knowledge is built in the minds of students themselves (Mecit, 2006).

Thematic learning using 21st Century skills is a higher order thinking skill (HOTS) that is very much needed in preparing students to face global challenges. 21st Century Skills are a 
Journal of Teaching and Learning in Elementary Education (JTLEE)

Vol. 3 No. 1, February 2020

(C)All rights reserved

Printed in Indonesia
ISSN (Print) : :2615-4528

ISSN (Online) : 2622-3023

DOI: http://dx.doi.org/10.33578/jtlee.v3i1.7825 series of stages of activities (phases) that are organized in such a way that students can master the competencies that must be achieved in thematic learning by playing an active role. Learning media are one of the right alternatives, although the materials and basic competencies have not changed, the format of the lesson plan has changed. learning media change and must be integrated with $4 \mathrm{C}$ capabilities, Literacy, HOTS and Character. Several studies have shown that the application of 21st century skills can improve students' critical thinking skills (Arifin, 2017), learning innovation (Muhlisin, 2017).

Based on the background of the above problems, a thematic lesson plan with 21st century skills will be developed for fourth grade elementary school students which is expected to facilitate teachers and students in thematic learning processes in elementary school and improve student learning activities and outcomes.

\section{CONTEXT AND LITERATURE}

The use of learning media is one of the determining factors for the success of a learning process. Development of learning devices see various components that exist in learning devices. The components certainly have different meanings, forms and formats. Trianto (2007: 68) explains that there are several components of learning media, among them can be in the form of lesson plans, teacher books, student books, worksheets, media, evaluation tools and so forth. In this study, learning media that will be developed are Learning Implementation Plan.

Learning Implementation Plan is a planning program that is prepared as a guideline for the implementation of learning for each learning process activity (Sanjaya. 2009: 59). Furthermore, Suprihatingrum (2013: 114) states that the learning implementation plan is a translation of the syllabus to direct the learning activities of students in an effort to achieve basic competencies. The preparation of the learning implementation plan should also look at the components contained in an Learning Implementation Plan. Components that compose an learning implementation plaN according to Ministerial Regulation No. 41 of 2007. Based on the opinion above, the learning implementation plan that will be developed in this study is in accordance with the stages of preparing the learning implementation plan according to National Education Minister's Regulation Number 41 of 2007 using 21st Century skills.

Education is a necessity that is needed by all people throughout the world. As explained in Chapter I, in science Indonesia is a developing country that is still lagging behind other developing countries. Nevertheless, education in Indonesia has advantages over these countries or other developed countries with basic education of the Pancasila and the 1945 Constitution which are rooted in the nation's culture 
Journal of Teaching and Learning in Elementary Education (JTLEE)

Vol. 3 No. 1, February 2020

(C)All rights reserved

Printed in Indonesia
ISSN (Print) : :2615-4528

ISSN (Online) : 2622-3023

DOI: http://dx.doi.org/10.33578/jtlee.v3i1.7825 that emphasizes the character that is indispensable in facing the challenges of the 21st Century. 21st Century learning is learning that integrates literacy skills, knowledge skills, skills and attitudes, and mastery of technology.

\section{21st Century Education}

Education that integrates knowledge skills, skills and attitudes, as well as mastery of ICT. These skills can be developed through various models of activity-based learning in accordance with the characteristics of competencies and learning materials. The skills needed in the 21st Century are also thinking skills higher (Higher Order Thinking Skills (HOTS)) which is very much needed in preparing students to face global challenges. In this section each of these skills will be discussed as follows.

\section{Critical Thinking Skills and Problem Solving Skills}

Critical thinking according to Beyer (1985) is: Critical thinking is the ability (1) determining the credibility of a source, (2) differentiating between relevant from irrelevant, distinguishing facts from judgment, (4) identifying and evaluating assumptions that are not spoken, (5) identifying existing biases, (6) identifying points of view, and (7) evaluating evidence offered to support recognition.

furthermore, Paul (1993): Critical thinking is a mode of thinking - about any matter, substance or problem - in which the thinker enhances the quality of his thought by handling skillfully the structures inherent in thought and applying intellectual standards to it. In this case also Walker (2006) states that: Critical thinking is an intellectual process in making concepts, applying, analyzing, synthesizing, and or evaluating various information obtained from observations, experiences, reflections, where the results of this process are used as a basis when taking action.

\section{Communication Skills}

According to the NACCCE (National Advisory Committee on Creative and Cultural Education) (in Craft, 2005), creativity is an imaginative activity that produces new and valuable work. Furthermore Feldman (in Craft, 2005) defines creativity as:

"the achievement of something remarkable and new, something which transforms and changes a field of endeavor in a significant way. . . the kinds of things that people do that change the world."

\section{Creativity and Innovation}

a) Having the ability to develop, implement, and convey new ideas orally or in writing.

b) Be open and responsive to new and different perspectives.

c) Able to express creative ideas conceptually and practically.

d) Use concepts or knowledge in new and different situations, both in related subjects, between subjects, and in contextual issues. 
Journal of Teaching and Learning in Elementary Education (JTLEE)

Vol. 3 No. 1, February 2020

(C)All rights reserved

Printed in Indonesia
ISSN (Print) : :2615-4528

ISSN (Online) : 2622-3023

DOI: http://dx.doi.org/10.33578/jtlee.v3i1.7825 e) Using failure as a vehicle for learning.

f) Having the ability to create novelty based on the initial knowledge possessed.

g) Able to adapt to new situations and make a positive contribution to the environment.

\section{Collaboration}

a) Have the ability to work in groups

b) Adapt in various roles and responsibilities, work productively with others.

c) Have empathy and respect for different perspectives.

\section{Development Research Model}

Plomp (1993: 1) describes development research based on two objectives, namely: (1) developing a product prototype, and (2) formulating methodological suggestions for designing and evaluating the prototype of the product. Development research methods are not much different from other research approaches. However, the development research focused on 2 stages, namely the preliminary stage and the formative evaluation stage (Tessmer, 1993: 2) which included self evaluation, prototyping (expert reviews and one-toone, and small groups), and field tests.

\section{RESEARCH METHODS}

This research is an educational research with design research model that develops a product. The product developed in this study is a thematic lesson plan with 21st century skills for grade IV elementary school. The research process adopted the steps proposed by Plomp, which was adopted from the Mckenney development model. According to Plomp (2013: 19) this model consists of three stages, namely: (1) preliminary research or preliminary analysis, (2) prototyping phase or design stage, and (3) assessment stage or assessment stage. This research was carried out to develop a product in the form of lesson plans with 21st century skills. in thematic learning for fourth grade students in the 2019/2020 Academic Year.

The assessment methods used in this study are as follows.

a. Self-evaluation.

b. Expert Review,

c. Individual Evaluation (One-to-one Evaluation),

d. Small Group Evaluation.

e. Field Test

\section{RESULT}

a. Preliminary Research Results (Preliminary Analysis)

The results of the curriculum analysis conducted revealed that the material taught was in accordance with the expected Basic Competence. Based on the 2013 curriculum, thematic learning is made in the form of themes. This is in line with learning with 21st century skills. With this 21st Century skill, students will discover lesson concepts through communicating, creative, collaborative, and critical thinking activities, so students 
Journal of Teaching and Learning in Elementary Education (JTLEE)

Vol. 3 No. 1, February 2020

(C)All rights reserved

Printed in Indonesia
ISSN (Print) : :2615-4528

ISSN (Online) : 2622-3023

DOI: http://dx.doi.org/10.33578/jtlee.v3i1.7825 will understand the concepts independently. Curriculum analysis is carried out by reviewing Basic Competence (KD) on Theme 2 Sub theme 2 Learning 1 . Curriculum analysis aims as a guideline in the development of thematic lesson plans based on 21st Century skill models for fourth grade students.

a) Concept Analysis Results

Concept analysis is the identification of the main material that will be discussed in learning. Concept analysis aims to arrange the order of material to be discussed. On the results of the formulation of indicators of achievement of competence and syllabus analysis of class IV thematic subjects SD. The material is arranged systematically using concept maps so that the material to be discussed can be seen specifically.

b) Results of Analysis of Student Characteristics

Analysis of the characteristics of students in this study was conducted on aspects of language development of students, intellectual development, and things that can enhance student learning activities. Analyzing the level of language development of students is used for consideration in compiling the worksheet language in a thematic learning implementation plan based on 21st Century skill models. While analyzing the learning activities of students is used for consideration in designing student activity sheet. Presentation in the lesson plan that invites interest or makes students motivated in learning.

\section{Results Prototyping Phase (Design Stage)}

\section{Prototype 1 results}

The results of this initial prototype design are named prototype 1 . The following will describe the characteristics of thematic learning implementation plans based on 21st Century skill models that have been designed.

The results of the design of the lesson plan in the initial stages are called prototype 1 . To obtain a valid lesson plan, the lesson plan is then validated. There are two steps taken in validation, namely conducting self-evaluation and discussing with experts.

a) Self Evaluation Results

The learning implementation plan that has been designed is evaluated by the learning implementation plan self evaluation instrument. After the evaluation, the learning kit was revised. Revisions were made to the lesson plan, namely mistakes in typing, such as pictures at the core activity stage in the lesson plan.

b) Results of Validation of Learning Devices by Experts

Learning media are then discussed with research partners. Then the learning device is validated by a validator. Lecturers who become validators come from 3 areas of expertise namely thematic (material), language, and design. Following are the results of learning implementation plan validation. Validation was carried out by 3 experts and carried out on several aspects of 
Journal of Teaching and Learning in Elementary Education (JTLEE)

Vol. 3 No. 1, February 2020

(C)All rights reserved

Printed in Indonesia
ISSN (Print) : :2615-4528

ISSN (Online) : 2622-3023

DOI: http://dx.doi.org/10.33578/jtlee.v3i1.7825 design, aspects of language, and material aspects.

After the validation process is complete, improvements are made to prototype 1 in accordance with the validator's suggestion. The results of the revision in prototype 1 are called prototype 2 . Before the practicality test is carried out, the researcher has also asked for expert opinion to estimate the practicality of the use of the designed learning device.

\section{One to one Evaluation Test Results (Prototype 2)}

One to one evaluation is done by giving a lesson plan (Prototype 2) to the teacher. One to one evaluation was held as many as one meeting, namely on November 26, 2018 at SDIT RAUDHATUL JANNAH, Lubuklinggau City. The teacher is asked to try out the lesson plan to two students with their respective abilities. After the students work on the worksheets, the students are given a questionnaire for the students' responses and interview instructions for the students.

\section{Small Group Evaluation Results (Prototype 3)}

Prototype 2 which has been revised in accordance with the results of one to one evaluation is called prototype 3 . Prototype 3 is also evaluated to see its practicality. Evaluation is done by conducting small group discussions or small group evaluations by practicing thematic learning implementation plans based on 21st Century skill models that have been designed for teachers with four grade IV students of SDIT RAUDHATUL JANNAH, Lubuklinggau, which come from high, medium, and low abilities. To assess the practicality of thematic learning implementation plans based on 21st Century skills models also use students' questionnaire responses and interview guidelines.

\section{Field Test Evaluation Results (Prototype 4)}

\section{a. Results Questionnaire Practicality} According to Teacher Response

The practicality test data of thematic learning implementation plan based on 21st Century skill models by teachers on thematic learning on the wide flat build material was obtained through teacher's questionnaire responses. Teacher response questionnaire data were obtained from grade IV teachers of SDIT RAUDHATUL JANNAH, Lubuklinggau (table 1).



Table 1. Results Assessment Questionnaire Practicality of Students Response 
Journal of Teaching and Learning in Elementary Education (JTLEE)

Vol. 3 No. 1, February 2020

(C)All rights reserved

Printed in Indonesia
ISSN (Print) : :2615-4528

ISSN (Online) : 2622-3023

DOI: http://dx.doi.org/10.33578/jtlee.v3i1.7825 b. Practicality Questionnaire Results According to Student Response

The practicality of thematic lesson plans based on 21st Century skills models for students was tested after students learned to use thematic learning implementation plans based on 21st Century skills models. Practicality questionnaires were given to students of SDIT RAUDHATUL JANNAH Lubuklinggau City with 20 people.

\section{c. Observation Results of Learning Implementation}

Observation of the implementation of learning aims to look at the practical aspects of the use of thematic lesson plans based on 21st Century skills models that have been designed in the learning process in terms of ease, clarity of learning, and use of time. Observations made by researchers. The results of observations of the implementation of learning using thematic learning implementation plans based on 21st Century skills models. Following is a description of the results of observations of the implementation of learning using thematic learning implementation plans based on 21st Century skills models.

\section{d. Results of Interviews with Teachers and Students}

Based on the results of interviews conducted with teachers, it was revealed that the thematic lesson plan based on 21st Century skills models was good enough to be applied, each step of the activity was considered attractive by the teacher and could increase the activity of students during the learning process.

\section{Discussion}

\section{Validity}

Validation results are collected and then analyzed to look for the average of each indicator and each aspect. Based on the content feasibility aspect, the thematic lesson plan based on the 21st Century skill model developed was declared valid by the validator with an average percentage percentage of $92 \%$ included in the very valid category. aspects of the format, thematic lesson plans declared valid with an average percentage value of $91 \%$ which includes valid categories. linguistic aspects, thematic lesson plans have been declared valid with an average percentage score of $93 \%$ included in the very valid category. aspect of graphic, thematic lesson plan is declared valid by the validator with an average percentage score of $96 \%$ which is categorized as very valid.

Based on the validity analysis of the thematic lesson plans by the validator, it can be concluded that the overall lesson plans that have been developed are included in the highly valid category with a percentage of the overall average value for the RPP of $92 \%$. A valid assessment of the thematic lesson plan indicates that the learning kit can be used as a thematic learning resource for fourth grade elementary school teachers and students in semester one. 
Journal of Teaching and Learning in Elementary Education (JTLEE)

Vol. 3 No. 1, February 2020

(C)All rights reserved

Printed in Indonesia
ISSN (Print) : :2615-4528

ISSN (Online) : 2622-3023

DOI: http://dx.doi.org/10.33578/jtlee.v3i1.7825

\section{Practicality}

Practicality test is carried out through several activities, namely one to one evaluation, small group and field tests. After getting advice from experts, the product is then revised according to the advice. Furthermore, the product is tested on students through a one to one evaluation test. One to one evaluation test was conducted on two grade IV students of SDIT RAUDHATUL JANNAH, Lubuklinggau City with different academic abilities. This test is carried out as much as one meeting with different material. At the end of the meeting students were asked to fill out a questionnaire and also conducted interviews. Based on the analysis of the practicality test results using a questionnaire in the one to one evaluation stage, an average of $93 \%$ was obtained with a very practical category.

\section{Effectiveness}

The term effectiveness in the Big Indonesian Dictionary (1990: 219) means the effect, effect, effect, impression. So, effectiveness means the impact, influence, and results that result from an action in this case on the use of learning media. Learning media can be said to be effective if they have a good impact on students' activities and cognitive development. Effectiveness can be done if the learning device has been declared valid and practical. The effectiveness of thematic lesson plans based on 21st Century skill models that are developed can be seen from the activities and learning outcomes of students. This effectiveness test was conducted six times in class IV SDIT RAUDHATUL JANNAH, Lubuklinggau.

\section{Conclusion}

This research is a development research that produces thematic lesson plans based on 21st Century skills models. Based on the results of the development and trials of thematic skills based on 21st Century skills models Lorscbach's model concludes as follows.

1. Thematic learning implementation plans based on 21st Century skill models have been produced with an aspects of the format, thematic lesson plans declared valid with an average percentage value of $91 \%$ which includes valid categories. linguistic aspects, thematic lesson plans have been declared valid with an average percentage score of $93 \%$ included in the very valid category. aspect of graphic, thematic lesson plan is declared valid by the validator with an average percentage score of $96 \%$ which is categorized as very valid. Based on the validity analysis of the thematic lesson plans by the validator, it can be concluded that the overall lesson plans that have been developed are included in the highly valid category with a percentage of the overall average value for the RPP of $92 \%$.

2. The practicality of thematic learning implementation plan based on 21st Century skill models as a whole is very 
Journal of Teaching and Learning in Elementary Education (JTLEE)

Vol. 3 No. 1, February 2020

(C)All rights reserved

Printed in Indonesia
ISSN (Print) : :2615-4528

ISSN (Online) : 2622-3023

DOI: http://dx.doi.org/10.33578/jtlee.v3i1.7825 practical. The practicality of thematic learning media is known from the results of questionnaire responses of students who have participated in learning using Thematic learning implementation plan based on 21st Century skill models with an average of $92.5 \%$, teacher response questionnaires using Thematic learning implementation plan based on 21st Century skill models with an average of $97 \%$ and interviews of students and teachers who are interested in teaching and learning using thematic lesson plans based on 21st Century skills models. These results illustrate that the use of learning media by teachers is very practical and can help increase students' interest in thematic learning.

3. The effectiveness of using thematic lesson plans based on 21st Century skills models can be known through observing students' learning activities, and student learning outcomes. Learning activities of students while learning by using this learning tool is very effective with an average of $80 \%$ and student learning outcomes with an average of $87.5 \%$ and are above the school KKM which is> 75. These observations illustrate that the use of thematic lesson plans based on 21st Century skills models has been effectively implemented.

\section{REFERENCES}

Depdiknas. 2006. Panduan Penyusunan Kurikulum Tingkat Satuan Pendidikan. Jakarta: Depdiknas.

Depdiknas. 2008. Pengembangan LKS. Jakarta: Departemen Pendidikan Nasional.

Ergin, I. 2012. Constructivist Approach Based TE Model And Usability Instructional Math. Turkish Military Academi. Turky. Journal Math Education 6 (1) 2012 online at http//www.lajpe.org. [diakses tanggal 7 April 2018].

Erviyana, G. 2012. Pengembangan LKS tematik Dengan keterampilan Abad 21 pada untuk Kelas IV di SD Negeri 7 Malang. Jurnal tematik Volume 4 No. 2 Juni 2014.

Mulyasa, E. 2009. Implementasi Kurikulum Tingkat Satuan Pendidikan Kemandirian Guru dan Kepala Sekolah. Jakarta: Bumi Aksara.

Peraturan Menteri Pendidikan dan Kebudayaan Nomor 22 Tahun 2016 Tentang Standar

Proses Pendidikan Dasar dan Menengah

Plomp, Tj. (2013). Educational Design: Introduction. From Tjeerd Plomp (eds). Educational \&Training System Design: Introduction. Design of Education and Training (in Dutch).Utrecht (the Netherlands): Lemma. Netherland. Faculty of Educational 
andTechnology, University of Twente.

Prastowo A. 2011. Panduan Kreatif Membuat LKS Inovatif. Yogyakarta: Diva Press.

Purwanto, D. 2014. Pengembangan Perangkat Pembelajaran (Silabus, learning implementation plan, PHB, Perangkat pembelajaran). Yogyakarta: Gava Media.

Riduwan \& Sunarto. 2012. Pengantar Statistika. Bandung: Alfabeta.
Sugiyono. 2011. Metode Penelitian Kuantitatif Kualitatif dan $R \& D$. Bandung: Alfabeta.

Trianto. 2010. Model Pembelajaran Terpadu: Konsep, Strategi dan Implementasinya dalam Kurikulum Satuan Pendidikan (KTSP). Jakarta: Bumi Aksara. 